\title{
Contested Spatial Coincidence of Conservation and Mining Efforts in Madagascar
}

\author{
Scott G. Cardiff' and Anjara Andriamanalina"
}

\begin{abstract}
Mining appears to represent an important threat to conservation efforts in Madagascar. Expanding mining activities on the island have the potential to provide revenue for development and conservation efforts, but also pose a potential threat to conservation efforts on the island due to the spatial distribution and extent of mining concessions and the environmental impacts that mines often cause. By measuring the extent of overlap of permitted mining concessions with protected areas, potential protected areas, and mining-exclusion zones on the island, we assessed potential effects of mining on terrestrial conservation and evaluated the success of the governing institutions in limiting that impact. Permitted mining areas in 2006 overlapped with protected areas, potential protected areas, and mining-exclusion zones on the island. Mining concession areas overlapped with $33 \%$ of surface area planned for protection in $2005,21 \%$ of surface area planned for protection in 2006 , and $12 \%$ of the surface area from which mining was to be legally excluded. Total permitted area and area of overlap with conservation areas increased between 2005 and 2006 despite efforts in 2004 to limit such overlap. Changes in the mining permitting and regulation could improve prospects for limiting the impact of mining on biodiversity conservation on the island.
\end{abstract}

\section{INTRODUCTION}

Mining has the potential to provide less industrially-developed countries (LDCS) with revenue that could promote development and reduce poverty, but expanded mining reforms are often unsuccessful in improving development indicators or national economic performance and lead to numerous harmful socioeconomic and environmental impacts (Miranda et al. 2003; Bridge 2004a; Davis and Tilton 2005; Haselip and Hilson 2005).

Madagascar faces potential conflicts between conservation and mining management. Since 2003, the government's Durban Vision effort has sought to triple the surface area of protected areas in order to protect six million ha of terrestrial and marine areas (Norris 2006) on this threatened island biodiversity hotspot (Myers et al. 2000). The Government of Madagascar and international financial institutions (IFIS), in the past decade, have also sought to promote a liberalized mining

\author{
Correspondence: \\ scott G. Cardiff \\ 1331 Pinewood Drive \\ Pittsburgh, PA 15243, USA \\ E-mail: sgc2102@columbia.edu
}

sector (Duffy 2005, 2007; Sarrasin 2006). New laws liberalizing, promoting, and regulating mining on the island were enacted in 1999-2001, 2003, and 2005 (Rép. Mad. 1999, 2000a, 2001, 2003a, 2005; Colored Stone 2005; Weldon 2005; Sarrasin 2006) and these policy changes have led to an increase in mine permitting and activity on the island (Cope 2002; Rép. Mad. 2003b; Bridge 2004b; Mining Journal 2004). Noted effects of existing mining efforts have included socio-economic and health impacts of uranium mining during the mid $-20^{\text {th }}$ century (Hecht 2002), socioeconomic and environmental impacts of gem mining rushes around Ambondromifehy / Ankarana and Ilakaka / Isalo (Walsh 2003, 2004; Cardiff and Befourouack 2003; Duffy 2005, 2007), and environmental impacts of certain industrial graphite and chromite mining operations (Rép. Mad. 2003b; Felena 2006).

The new mining regulations gave some consideration to environmental impacts of mining. The current mining policy requires that mining entities conduct environmental studies and plans according to the types of mining activity and permit requested (Table 1; Duffy 2007). The Ministère de l'Energie et des Mines (MEM) can also declare certain zones as reserved in order to protect conservation sites, sites with fossils, or other sites decided by the MEM (Rép. Mad. 1999, 2000a). Due to perceived problems with the mine permitting process (Rép. Mad. 2003b), permit granting in various conservation areas was even formally halted beginning in 2004 and extended through 2008 in order to designate mining-exclusion or "no-go" zones (Rép. Mad. 2004; Borrini-Feyerabend and Dudley 2005; Norris 2006; Duffy 2007; Rép. Mad. 2007). The mine-forests commission (Comité / Commission Interministériel des Mines et des Forêts), officially decreed in 2004, also began to work to resolve and prevent overlap of mining permits with conservation zones (Rép. Mad. 2007).

Although others have noted overlap of potential mining areas with areas of importance to conservation on the island (Rép. Mad. 2003b; Duffy 2005, 2007; F. Hawkins personal communication), a recent quantitative evaluation of the spatial intersection of actual permitted concessions with a complete set of types of conservation areas over time remains lacking.

We sought to conduct such an analysis and determine current evidence of conflict between mining and conservation objectives in Madagascar by evaluating spatial coincidence of 
TABLE 1. Regulatory characteristics of mining permits in Madagascar (Rép. Mad. 2000b; BPGRM 2002). Exploitation permits may allow for the most intensive environmental impacts, but their spatial extent is more limited than that of research permits. Plans d'Engagement Environnementales (PEE) represent less stringent environmental impact planning than Etudes d'Impactes Environnementales (EIE). New regulations are expected to change grid square size and other conditions in 2007.

\begin{tabular}{|c|c|c|c|c|c|c|c|c|}
\hline $\begin{array}{l}\text { NAME OF PERMIT TYPE } \\
\text { (ABBREVIATION) }\end{array}$ & $\begin{array}{l}\text { SPATIAL EXTENT } \\
\text { ALLOWED }\end{array}$ & $\begin{array}{l}\text { MAXIMUM } \\
\text { DURATION }\end{array}$ & $\begin{array}{l}\text { PROSPECTING } \\
\text { ALLOWED? }\end{array}$ & $\begin{array}{l}\text { RESEARCH } \\
\text { ALLOWED? }\end{array}$ & $\begin{array}{l}\text { EXTRACTION } \\
\text { ALLOWED? }\end{array}$ & $\begin{array}{l}\text { TECHNOLOGY } \\
\text { ALLOWED }\end{array}$ & $\begin{array}{l}\text { ENVIRONMENTAL } \\
\text { PLANS REQUIRED }\end{array}$ & $\begin{array}{l}\text { SALE OF SUBSTAN- } \\
\text { CES ALLOWED? }\end{array}$ \\
\hline $\begin{array}{l}\text { Authorisation Exclusive } \\
\text { de Réservation de } \\
\text { Périmètre (AERP) }\end{array}$ & $\begin{array}{l}2,400 \\
\text { grid squares }\end{array}$ & $3 \mathrm{mo}$ & yes & no & no & undefined & $\begin{array}{l}\text { none } \\
\text { PEE; EIE }\end{array}$ & no \\
\hline $\begin{array}{l}\text { Permis Réservé aux } \\
\text { petits Exploitants (PRE) }\end{array}$ & $\begin{array}{l}16 \\
\text { grid squares } \\
\text { (4 per block) }\end{array}$ & $\begin{array}{l}8 \mathrm{yrs} \\
+4 \mathrm{yrs} \\
\text { extensions }\end{array}$ & yes & yes & yes & manual & PEE; $\mathrm{EIE}^{1}$ & yes \\
\hline Permis de Recherche (R) & $\begin{array}{l}1,600 \\
\text { grid squares }\end{array}$ & $\begin{array}{l}10 \mathrm{yrs} \\
+5 \mathrm{yrs} \\
\text { extensions }\end{array}$ & yes & yes & no & mechanized & PEE; $\mathrm{EIE}^{2}$ & no \\
\hline Permis d’Exploitation (E) & $\begin{array}{l}160 \\
\text { grid squares }\end{array}$ & $\begin{array}{l}40 \mathrm{yrs} \\
+20 \mathrm{yrs} \\
\text { extensions }\end{array}$ & yes & yes & yes & mechanized & EIE & yes \\
\hline
\end{tabular}

${ }^{1}$ Regulations require PRE permits to file EIE if in areas with high concentrations of miners ( $>20$ within 500m radius)

${ }^{2}$ Regulations require $\mathrm{R}$ permits to file EIE if in sensitive areas, if demanded by a prior PEE, or if being transformed to an E permit

areas with the various mining permits issued by MEM (Table 1) and current and potential protected areas and mining-exclusion ("no-go") zones. We also assessed temporal change in potential conflict between conservation and mining objectives, and examined how new temporarily protected areas corresponded with previous protection plans.

\section{METHODS}

To establish the locations of mining permits, we acquired the database of mining permits of 9 June 2006 from the Bureau du Cadastre Minier de Madagascar (BCMM) of the Ministère de I'Energie et des Mines of the Government of Madagascar. We also obtained that database from 3 May 2005 and the database of mining-excluded grid squares $(2.5 \times 2.5 \mathrm{~km}$ "carrés") from 3 May 2005 from ANGAP (Association Nationale pour la Gestion des Aires Protégées / Parcs Nationaux de Madagascar).

We used several different geographic coverages to represent areas of conservation importance on the island. We obtained a geographic database consisting of the locations of protected areas established prior to 2005 and new protected areas that were to have been created in 2005 and 2006 and projected to be created in 2007-2008 in accordance with the planned Système d'Aires Protégées de Madagascar (SAPM; Durban Vision unpublished data). The 2007-2008 zones represented remaining forest that could potentially become protected area rather than distinct planned protected areas; many of these areas may have become degraded since the original categorization of the forest lands. We also examined classified forests (forêts classées) and forest reserves (réserves forestières) managed by the Ministère de I'Environnement, des Eaux et Forêts. Some of these latter forest areas, some SAPM areas, and some mining-exclusion areas coincided with one another. We also used a geographic database containing spatial information on new, temporarily protected areas established in 2005-2006 to compare with previous SAPM protection plans.

We measured the extent of overlap of areas with mining permits with areas of potential conservation importance using ArcGIS 8.3 (ESRI, Redlands, California). We approximated a Laborde projection using a standard Hotine Oblique Merca- tor projection for all shapefiles. Intersected area measured was the area in common between mining grid squares and conservation area and assumed the shape of the intersection regardless of grid square boundary shape. We measured overlap of permitted mining grid squares from 2006 with SAPM areas, with classified forests and forest reserves, and with mining-exclusion areas listed in 2005. To better understand the potential impacts of permitting practices, we also analyzed characteristics of permits (type of permit, permitted substance, permit dates, and types of overlapped mining exclusion zones) granted for overlapped conservation areas. Some permits did not have starting permit dates in the databases; $3 \%$ of permitted grid squares in 2005 and, after filling in missing dates where possible from matching permits from the 2005 database, $8 \%$ of permitted grid squares in 2006 did not have starting permit dates. We also included in our analyses permits, representing $5 \%$ of the permitted grid squares listed in 2006 , that ought to have expired within a year prior to the database date because their continued presence in the database may have implications for mining activity in the field.

Possible differences in digitizing practices or projections between agencies represented a minor potential source of error in the analysis. As an indication of the small magnitude of this error, however, discrepancy between grid square surface areas for overlapping permitted grid squares listed in 2005 with those of 2006 and permitted grid squares from 2006 with overlapping exclusion zone grid squares averaged only $0.02 \%$ ( $\pm 0.001 \%$ SE) and $0.02 \%( \pm 0.004 \% \mathrm{SE})$ per grid square for those respective comparisons. For our analyses we also assumed that official boundaries in spatial databases for SAPM areas were accurate, but official limits for some existing protected areas may also have differed from border markers and acknowledged limits on the ground (e.g., Cardiff and Befourouack in press), and so overlap of permitted mining zones with current SAPM areas in the field may differ slightly from what we measured.

In order to evaluate the pace of mining activity on the island and the change in its relevance to conservation efforts, we measured the change in number of grid squares with mining permits between our permit lists from 2005 and 2006, the 
number of grid squares granted new permits in several consecutive years, and the change in area of overlap with all pre-2007 existing and planned SAPM areas over several years. Finally, we measured the proportion of the total mining concession surface area that overlapped with SAPM zones, and measured surface area of the total remaining new and potential SAPM area that remained free of mining permits.

\section{RESULTS}

Mining areas with permits in 2006 overlapped with several categories of protected, potentially protected, forested, and mining-exclusion zones (Figure 1; Table 2). Greatest area of overlap occurred with mining-exclusion zones, and greatest proportional overlap occurred with 2005 SAPM areas (Table 2).

The greatest surface area of overlap for all 2006-listed permitted grid squares with SAPM 2005-6 zones occurred in the North (Makira and Daraina), the Southwest (Mikea) and the center-east (Ranomafana-Andringitra; Table 3). Less overlap of mining concessions occurred with a few pre-2005 protected areas (Table 3). Overall area of overlap of mining concessions of all permit types with SAPM 2005-6 areas increased between 2005 and 2006; overlap of small exploitation (PRE) and exploitation (E) permits with those SAPM areas increased between 2003 and 2005 before decreasing (Table 3). Between 16 and $67 \%$ of the 2006 -listed grid squares that overlapped with SAPM areas of different years started after the decree stopping permitting in conservation zones from mid-October 2004 (Table 2). Gold or ilmenite featured as the most commonly permitted primary substance for several categories of conservation areas (Table 2). Most of the permitted surface area overlapping with SAPM areas was under research permits ( $R$; Table 2). Surface area of overlap of mining concessions with the combined SAPM areas represented only $6 \%$ of the total area in the country with 2006 - listed mining permits.

Most of the mining-exclusion zone surface area with overlapping 2006 - listed permits was also under research permits ( $R$; Table 2). Approximately half of that overlapped area consisted of zones that were excluded because they were conservation sites (Table 4), and these overlapped conservation exclusion zones represented $16.8 \%$ of all conservation exclusion zones by surface area (Table 2). A total of $68 \%$ of mining-excluded conservation site surface area with mining permits coincided spatially with SAPM areas from 2005 to 2008. Most of the permitted yet officially mining-excluded grid squares with starting dates had starting dates after the date of the permit halt decree of 2004 (Table 2).

Surface area with mining permits increased between May 2005 and June 2006, with 12,735 grid squares having permits in both years, 1,813 grid squares losing permits between 2005 and 2006 , and 15,417 grid squares receiving new permits. The majority of the newly permitted grid squares between May 2005 and June 2006 were AERP permits. Ignoring AERP permits, the total number of permitted mining grid squares also increased between 2000-2002 and 2003, and between 2003 and 2004 (Figure 2).

The sum of the surface area of pre-2005 protected areas added to the area of 2005-2008 planned, potentially protected areas that did not also have mining permits was 7.4 million ha.

Although time lags and differences in size and shape occurred, all planned 2005 SAPM protected areas received temporary protection by 2007 (Figure 3; Table 3). Most planned

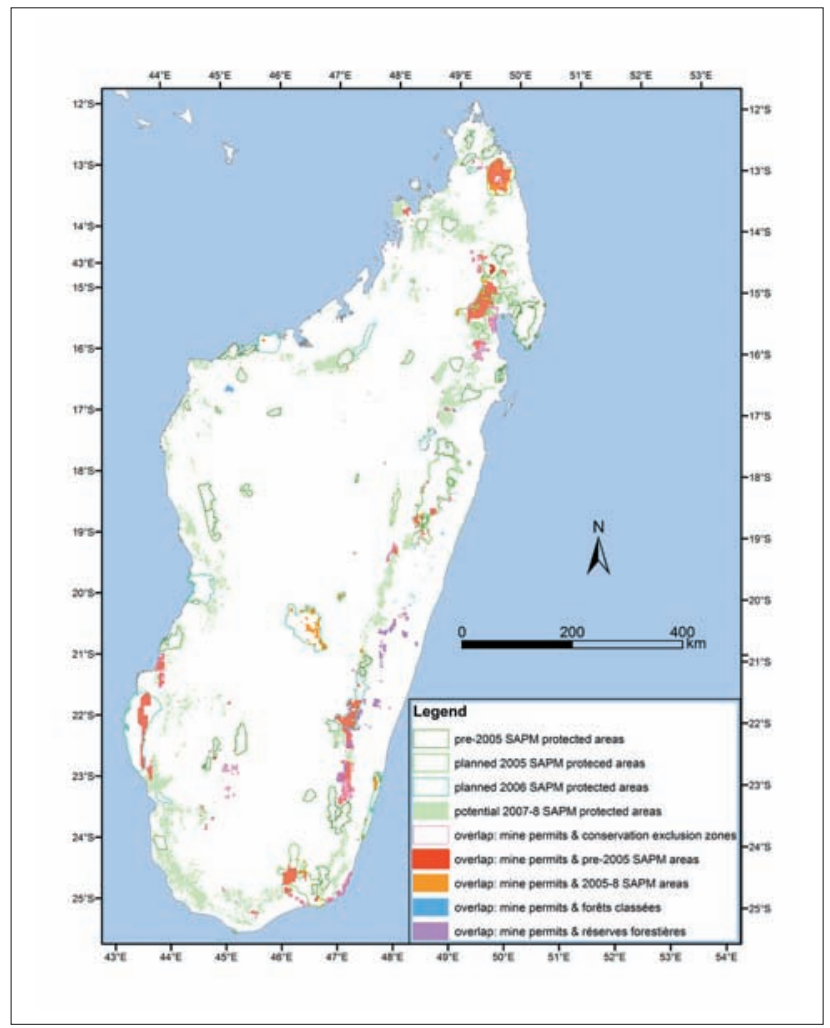

FIGURE 1. Map illustrating overlap of mining permits on list from 09 June 2006 with all areas of conservation importance that we assessed. The map shows permit overlap with forêts classées and réserves forestières only where overlap does not also correspond with permit overlap with SAPM areas. We did not illustrate the overlap of permits with exclusions zones other than conservation exclusion zones (see Table 4) and did not illustrate the post-2004 SAPM areas that have received temporary protection. Overlap with pre-2005 SAPM areas is enlarged for visibility.

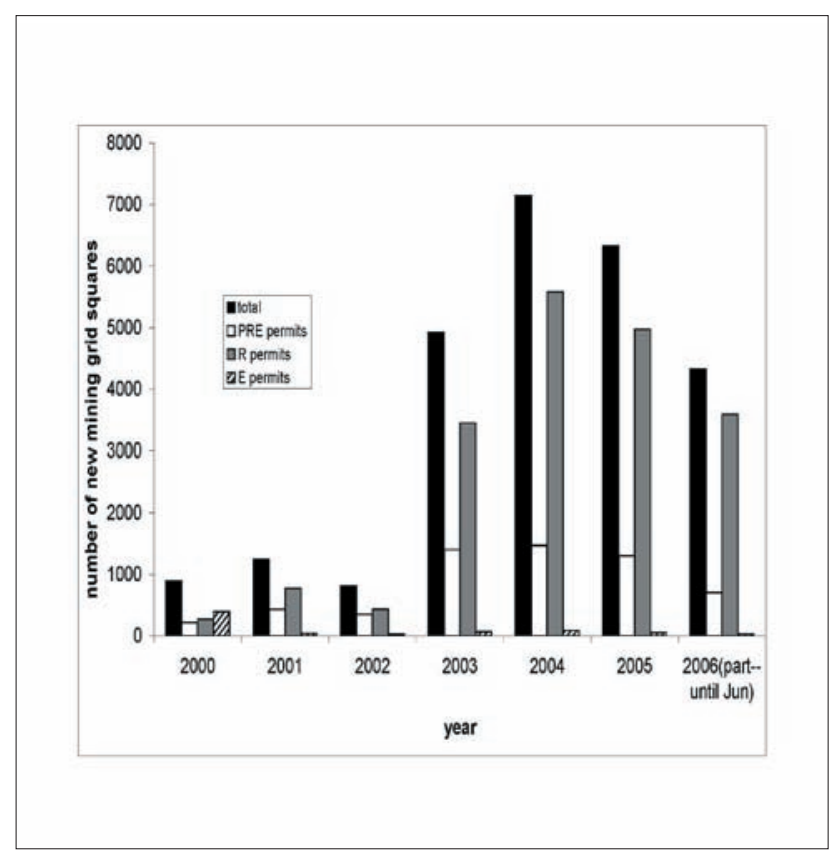

FIGURE 2. Number of mining grid squares granted small exploitation (PRE), research (R), and exploitation (E) permits in 2000-2003 (Mining Journal, 2004), 2004 (based on permit dates from list of May 2005), 2005, and June 2006 (latter two based on permit dates from list of June 2006). Counts for 2004 and 2005 may not include some permits that were obtained during those years but expired before the date of the database that we used to generate the count. Proportions of the permitted grid squares also lacked start dates in the $2005(0.05 \%)$ and 2006 (12\%) databases. Total = PRE + R +E. 
TABLE 2. Mining permits listed in June 2006 overlapped with all types of categories of areas of conservation importance examined. Permits for all overlapped areas had expiration dates ranging until at least 2039 and substances sought included gold for almost all categories. SAPM = Système d'Aires Protégées de Madagascar. Percentage of permits since decree represents the percentage of mining grid squares with starting dates occurring after the date of application of the 2004 decree halting permitting in conservation exclusion zones.

\begin{tabular}{|c|c|c|c|c|c|c|c|}
\hline $\begin{array}{l}\text { OVERLAPPING } \\
\text { PERMIT CHARAC- } \\
\text { TERISTIC }\end{array}$ & $\begin{array}{l}\text { PRE-2005 SAPM } \\
\text { AREAS }\end{array}$ & $\begin{array}{l}2005 \text { SAPM } \\
\text { ADDITIONS }\end{array}$ & $\begin{array}{l}2006 \text { SAPM } \\
\text { ADDITIONS }\end{array}$ & $\begin{array}{l}\text { 2007-8 SAPM } \\
\text { ADDITIONS }\end{array}$ & $\begin{array}{l}\text { FORÊTS } \\
\text { CLASSÉES }\end{array}$ & $\begin{array}{l}\text { RÉSERVES } \\
\text { FORESTIËRES }\end{array}$ & $\begin{array}{l}\text { MINING EXCLU- } \\
\text { SION ZONES (AND } \\
\text { CONSERVTION SITE } \\
\text { EXCLUSION ONLY) }\end{array}$ \\
\hline \multicolumn{8}{|l|}{$\begin{array}{l}\text { surface area (ha) } \\
\text { by permit type }\end{array}$} \\
\hline AERP & 0 & 7,397 & 47,681 & 3,639 & 5,270 & 14,532 & 137,446 \\
\hline PRE & 294 & 41,527 & 38,515 & 12,880 & 8,190 & 23,566 & 213,035 \\
\hline $\mathrm{R}$ & 546 & 450,080 & 252,739 & 203,799 & 41,789 & 193,382 & $1,992,797$ \\
\hline$E$ & 92 & 7,789 & 5,609 & 5,385 & 8,240 & 1,379 & 83,868 \\
\hline total & 932 & 506,794 & 344,544 & 225,704 & 63,489 & 232,858 & $2,427,146$ \\
\hline $\begin{array}{l}\text { percentage of } \\
\text { total area for } \\
\text { category }\end{array}$ & 0.05 & 32.6 & 20.9 & 6.3 & 2.7 & 23.0 & $12.1(16.8)$ \\
\hline $\begin{array}{l}\text { median starting } \\
\text { date }\end{array}$ & 2005 & 2003 & 2003 & 2003 & 2004 & 2004 & 2004 (2004) \\
\hline $\begin{array}{l}\text { median expiration } \\
\text { dates }\end{array}$ & 2015 & 2014 & 2011 & 2014 & 2014 & 2013 & 2014 (2014) \\
\hline $\begin{array}{l}\text { starting dates } \\
\text { range }\end{array}$ & $1995-2006^{1}$ & $1991-2006^{2}$ & $1991-2006$ & $1992-2006$ & $1935-2006$ & $1994-2006$ & $\begin{array}{l}1913-2006 \\
(1992-2006)\end{array}$ \\
\hline $\begin{array}{l}\text { expiration dates } \\
\text { range }\end{array}$ & 66.7 & 34.3 & 2006-2041 & $2006-2044$ & $2006-2043$ & $2006-2041$ & $\begin{array}{l}2005-2046 \\
(2006-2046)\end{array}$ \\
\hline $\begin{array}{l}\text { percentage of } \\
\text { permits since } \\
\text { decree }\end{array}$ & 2011-2039 & $2006-2043$ & 41.1 & 16.3 & 29.8 & 52.6 & $52.5(60.7)$ \\
\hline $\begin{array}{l}\text { minerals with } \\
\text { greatest permited } \\
\text { area, \% of area }\end{array}$ & $\begin{array}{l}\text { gold-diamond, } \\
58\end{array}$ & $\begin{array}{l}\text { gold-other, } \\
65\end{array}$ & $\begin{array}{l}\text { ilmenite-other, } \\
40\end{array}$ & $\begin{array}{l}\text { corundum-other, } 34 \\
\text { ilmenite-other, } 28 \\
\text { gold-other, } 19\end{array}$ & $\begin{array}{l}\text { gold-other, } 36 \\
\text { copper-other, } 24\end{array}$ & $\begin{array}{l}\text { corundum-other, } 57 \\
\text { gold-other, } 27\end{array}$ & $\begin{array}{l}\text { gold-other, } 36 \\
\text { (gold-other 31) }\end{array}$ \\
\hline
\end{tabular}

A permit for mica mining in Andohahela Parcelle III dated from 1965

${ }^{2}$ A permit for mica mining in the Atsimo area dated from 1965

TABLE 3. Change in surface area between 2003 and 2006 of overlap of zones with mining permits with different SAPM (Système d'Aires Protégées de Madagascar) areas. Recorded 2003 overlap (Rép. Mad. 2003b) only represented exploitation (E) and small exploitation (PRE) permits. We did not include planned 2007-8 SAPM areas in this analysis.

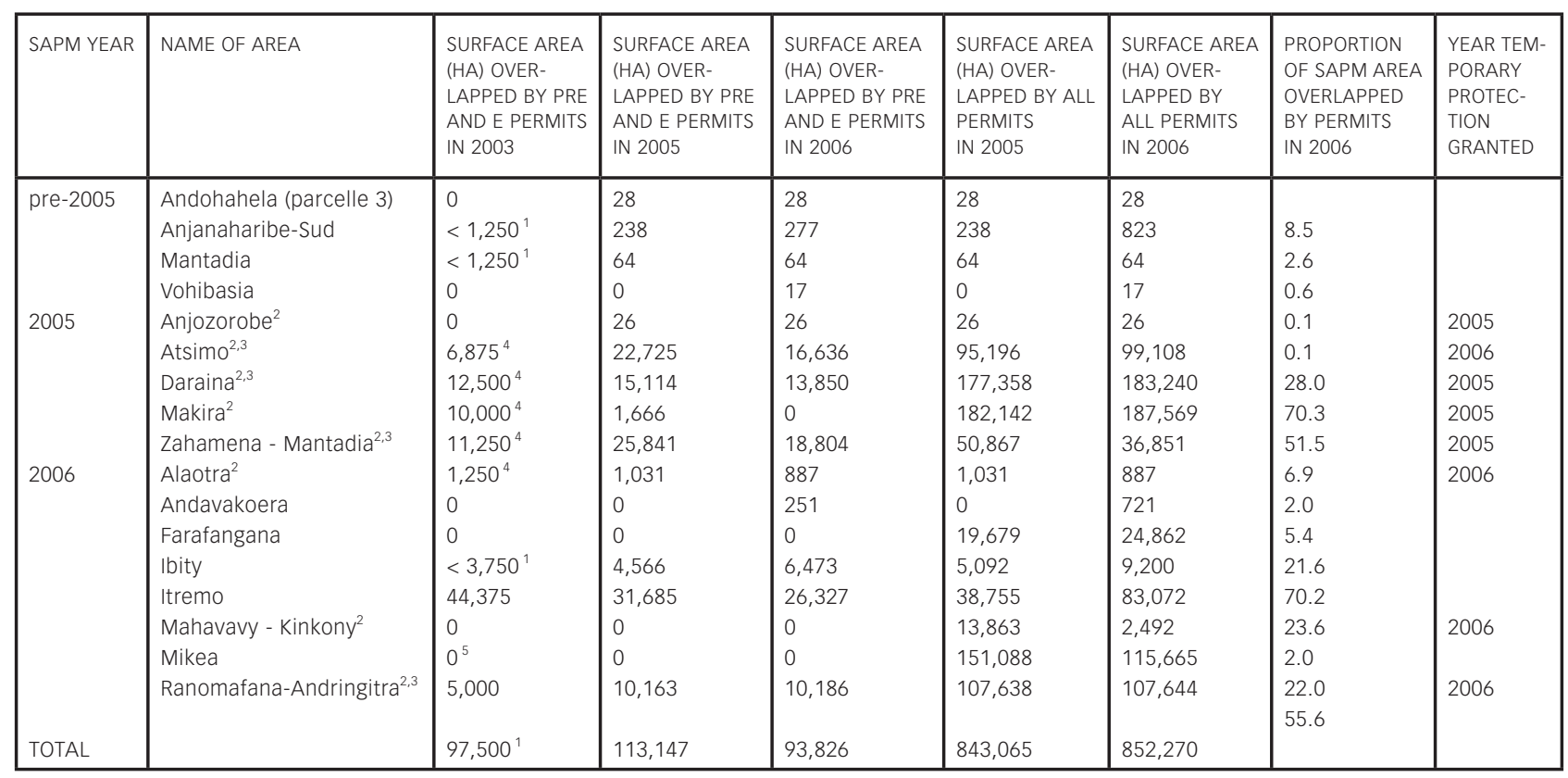

'overestimate because individual mining grid squares only partially overlapped with SAPM areas; ${ }^{2}$ corresponding temporarily protected area differed in shape and surface area (smaller or larger) from this original SAPM listing; ${ }^{3}$ corresponding temporarily protected area(s) differed in name(s) from this original SAPM name listing; ${ }^{4}$ counted grid squares as per SAPM 2005 delimitation not as per map in Rép. Mad. (2003b); ${ }^{5}$ overlap mentioned in text but not shown (possibly R or AERP permit overlap) 


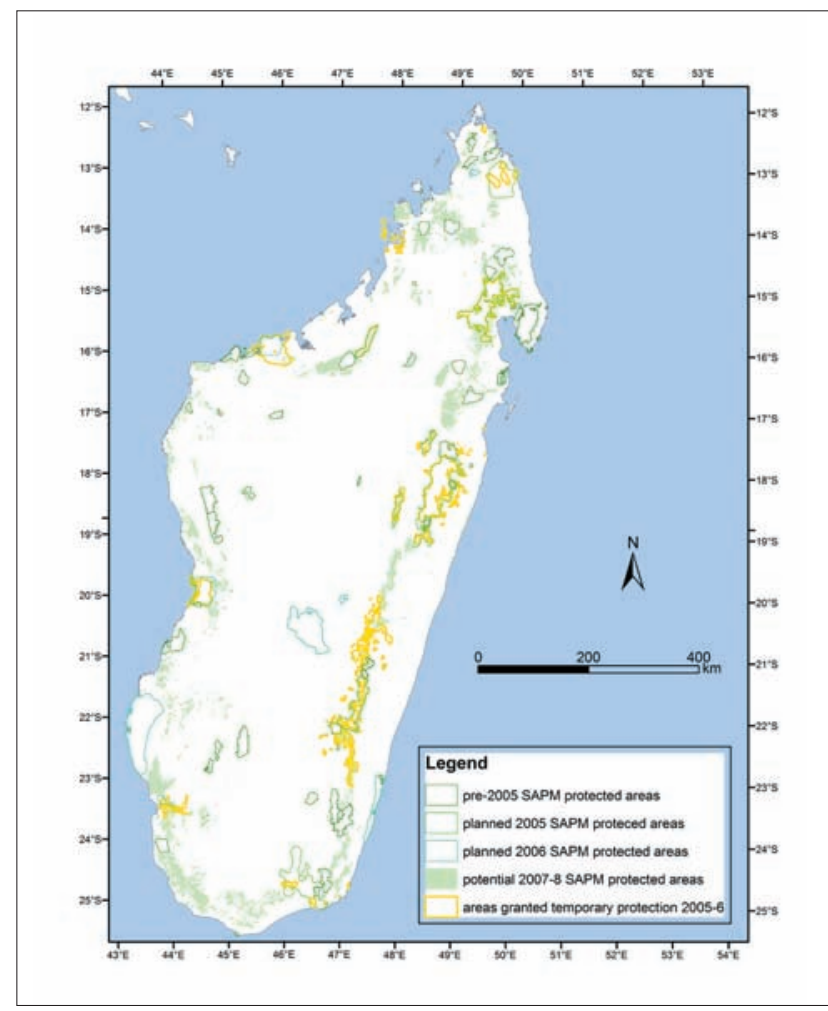

FIGURE 3. Geographic correspondence between planned SAPM protected areas for 2005-2006 and areas actually temporarily protected in 2005-2006. Temporary protection zones differed in size and shape from SAPM plans for 2005 and 2006, and most planned 2006 areas, which had extensive mining permit overlap, remained unprotected by early 2007 . Names and mining permit overlap proportions of planned areas are in Table 3.

2006 SAPM protected areas, however, had yet to receive temporary protection by 2007 (Figure 3; Table 3).

\section{DISCUSSION}

The area of overlap of actual mining concessions with areas that were listed as mining-exclusion zones and current and potential SAPM protected areas suggests that current regulation of the mining industry in Madagascar may be insufficient to conserve areas with important biodiversity. This appears to validate concerns that institutional changes associated with mining liberalization and structural adjustment may prevent the government from properly managing an expanding mining industry (Rép. Mad. 2003b; Ramamonjisoa 2004; Sarrasin 2006; Duffy 2007). Mining interests in Madagascar may displace or alter planned conservation efforts as they have in countries such as Australia (Pouliquen-Young 1997), Guyana (Funk et al. 1999), and French Guiana (Thiollay 2002).

OTHER EXPLANATIONS? The difference in database dates for the permit list (2006) and the exclusion zone list (2005) might have influenced measured overlap with exclusion zones. The overlap could actually have reflected a reduction in the list of exclusion-zone areas between those years, as suggested by the title of an ordinance from 2005 (Rép. Mad. 2007), or the unrecorded suspension of mining permits once new exclusion zones were put in place. Examination of a printed map of the Daraina region from BCMM from June 2006, however, confirmed the presence of official overlap between exclusion sites and permitted mining grid squares (SGC unpublished data). Most of the overlapped exclusion zones were also excluded
TABLE 4. Conservation sites (Site de conservation) were the mining exclusion zone sub-category with the greatest surface area of overlap by mine permits listed in June 2006, but overlap occurred for other sub-categories

\begin{tabular}{|c|c|c|c|}
\hline $\begin{array}{l}\text { CATEGORY OF } \\
\text { EXCLUSION ZONE }\end{array}$ & $\begin{array}{l}\text { SUB-CATEGORY OF } \\
\text { EXCLUSION ZONE }\end{array}$ & $\begin{array}{l}\text { OVERLAP } \\
\text { SURFACE AREA } \\
\text { (HA) }\end{array}$ & $\begin{array}{l}\text { PERCENTAGE } \\
\text { OF TOTAL OVER- } \\
\text { LAPPED EXCLU- } \\
\text { SION ZONES } \\
\text { REPRESENTED } \\
\text { BY EXCLUSION } \\
\text { SUB-CATEGORY } \\
(\%)\end{array}$ \\
\hline $\begin{array}{l}\text { Forêts classées } \\
\text { Parcs nationaux } \\
\text { Zones Fossiliferes } \\
\text { Zones réservées } \\
\text { Zones Tampon }\end{array}$ & $\begin{array}{l}\text { Forêts classées } \\
\text { Parcs nationaux } \\
\text { Zones Fossiliferes } \\
\text { Site de conser- } \\
\text { vation } \\
\text { Zone d'étude } \\
\text { géologique } \\
\text { OMNIS } \\
\text { "ASS_OR” } \\
\text { "Zones réservées" } \\
\text { "Z_QMM" } \\
\text { Zones Tampon }\end{array}$ & $\begin{array}{r}70,519 \\
1,874 \\
230,054 \\
1,222,603 \\
\\
695,765 \\
\\
136,288 \\
70,519 \\
31,270 \\
22,473 \\
5,005\end{array}$ & $\begin{array}{r}2.8 \\
0.1 \\
9.3 \\
49.2 \\
\\
28.0 \\
\\
5.5 \\
2.8 \\
1.3 \\
0.9 \\
0.2\end{array}$ \\
\hline
\end{tabular}

for conservation reasons and the overlap may be of conservation importance even if the exclusion were removed. Many of the overlapping permits were also granted in 2006 and were therefore too recent to have been unofficially suspended by the institution of the exclusion zones from 2005.

CONSERVATION COMPATIBILITY? The approval of temporary or permanent protection for several SAPM areas with mining overlap in recent years, the larger size than originally planned for some of those areas, and the subsequent decrease in permits in some of those areas might suggest that resolution of potential conflicts favors conservation outcomes. Indeed, the mines-forests interministerial commission is intended to prevent conflict between conservation and mining interests and has generally facilitated limiting mining permits on new temporarily-protected areas (J. Mackinnon personal communication), but old permits remained on several of those new temporarily-protected areas and permits granted since temporary protection appeared to overlap slightly with those areas at Anjozorobe and Ankeniheny Zahamena (SGC unpublished data). Remaining potential SAPM surface area without mining permits was theoretically sufficient to cover the goals of the Durban Vision. Many forest areas considered potential SAPM areas, however, may have become degraded since the drafting of the initial SAPM plans that were based on earlier forest cover information, and further mine permitting may threaten remaining forest area.

CAUSES FOR CONCERN Several observations indicate

that current mining plans and conservation goals may not be compatible:

- Mining permits overlapped with all categories of conservation areas and covered up to $33 \%$ of the surface area of a given conservation category.

- Permit-granting appeared to have continued in mining-exclusion zones and SAPM areas in spite of government efforts to halt such overlap in 2004 and 2006 (Rép. Mad. 2004, 2007).

- The duration of permits granted in areas of conservation concern and the potential high value of the gold to be extracted suggest that granting those permits may not have been a temporary mistake. 
- $\quad$ The number of grid squares with permits also tended to increase since 2002 and the number of non-AERP permits granted in the first half of 2006 also suggests an increasing rate of permitting. Overlap of mining concessions with SAPM areas appears to have increased at least between 2003 and 2005 as well. Although many of the overlapping permits are research permits that may lead to less intensive but more extensive impacts, small (PRE) and large (E) exploitation permits also overlapped frequently with conservation areas.

- The temporary protection granted to some new SAPM areas may expire prior to granting of permanent protection (USAID unpublished report) and the extension of the ban on permitting in the exclusion zones will expire in 2008 (Rép. Mad. 2007).

- $\quad$ Some new temporarily-protected areas are smaller than originally planned, and five of the areas that were originally scheduled to receive protection in 2006, and that had overlapping mining permits, had yet to receive even temporary protection.

- Granting of exploitation permits may exclude conservation efforts in potential SAPM 2007-8 areas where conservation plans are not sufficiently advanced to establish temporary protection. Additional work ought to examine how potential competition for certain areas by conservation and mining interests may have influenced temporal and spatial distribution of granting of official SAPM protection and granting of mining permits.

- The "governance state," consisting of a combination of the authority of the state, IFIs, development agencies, private corporations, and NGOs (Duffy 2006), has failed to adequately manage and limit impacts of existing artisanal mining efforts, which can accompany or follow large-scale mining (Hilson 2002), at several locations in Madagascar over the past decade (Walsh 2003; Rép. Mad. 2003b; Cardiff and Befourouack 2003; Duffy $2005,2007)$. We did not assess the impact of smallscale artisanal mining but this sector may expand in conjunction with the expansion of the overall mining sector and have significant conservation impacts.

- We did not consider overlap with protected area buffer zones or locally-protected areas in our analysis, but such overlap could threaten conservation around and within those areas.

- Freshwater aquatic biodiversity on the island may suffer from mining activities given that Madagascar is classified as a country that is very highly vulnerable and predisposed to water quality problems from mining and that water pollution and over-use are common consequences of mining (Miranda et al. 2003).

- The expanding off-shore and on-shore petroleum extraction industry in Madagascar (Yager 2004) will most likely affect Malagasy marine and terrestrial conservation.

\section{CONCLUSIONS}

Mining in Madagascar may have the potential to provide revenue for projects that support conservation and development goals. Mining in degraded savannah may have relatively limited negative impact on biodiversity conservation on the island, although such mines could still cause local socio-economic problems, adversely affect soil and water conservation and quality, and contribute to larger economic processes with additional severe global environmental impacts such as climate change (Bridge 2004a). Given the large proportion of mining-permitted area that was outside of areas of conservation importance $(94 \%$ outside of SAPM planned areas), restricting mining to areas away from forested conservation zones seems feasible even if many mineral resources occur below remaining forested areas. Restriction of mining to savannah would help prevent fragmentation of areas that can still contribute to the goals of the Durban Vision and biodiversity conservation and would help protect the availability of forest products for people who depend on them.

Management of the mining industry as of July 2006, however, appears to provide inadequate protection to forested areas and terrestrial areas of conservation concern on the island. Reversing permitting and expanding and enforcing a ban on mine permitting in areas of conservation importance would most likely improve prospects for biodiversity conservation on the island. Increased direct foreign aid for sustainable development such as health and education programs could potentially provide desired development outcomes without the negative environmental and socioeconomic impacts likely to accompany mining sector expansion.

\section{ACKNOWLEDGEMENTS}

We would like to thank Tsiory Razafindrazaka, ANGAP, and Frank Hawkins for providing or advising on use of spatial information. We also acknowledge the Ministère de l'Energie et des Mines and the Bureau du Cadastre Minier de Madagascar for selling us the database of mining permits. This material is based upon work supported under a National Science Foundation Graduate Research Fellowship. Steven M. Goodman, James Mackinnon, Jade Sasser, Andrew Walsh, Lucienne Wilmé, and two anonymous reviewers kindly provided valuable comments on a previous version of this manuscript. We also thank Martin Nicoll for his assistance with mining policy references. Carlos Ivan Zambrana Flores and Lucienne Wilmé graciously assisted with GIS analysis.

\section{REFERENCES}

Borrini-Feyerabend, G., and Dudley, N. 2005. Elan Durban. Nouvelles perspectives pour les Aires Protégées de Madagascar. http://www.pnae. mg/chm-cbd/implementation/doc/sapm/les_ap_mcar_elan_durban. pdf

BPGRM. 2002. Base de Données Pour la Gouvernance des Ressources Minérales. Guide pour les opérateurs miniers à l'usage du cadastre minier. http://www2.gaf.de/bpgrm/pdf/law-mining/guide.pdf

Bridge, G. 2004a. Contested terrain: mining and the environment. Annual Review of Environment and Resources 29:205-259.

Bridge, G. 2004b. Mapping the bonanza: geographies of mining investment in an era of neoliberal reform. The Professional Geographer 56:406421.

Cardiff, S. and Befourouack, J. 2003. The Réserve Spéciale d'Ankarana. In: The Natural History of Madagascar, S.M. Goodman and J.P. Benstead (eds.), pp 1501-1507. University of Chicago Press, Chicago.

Cardiff, S., and Befourouack, J. In press. La Réserve Spéciale d'Ankarana. In: Paysages naturels et biodiversité à Madagascar, ed. S.M. Goodman. Muséum national d'Histoire naturelle, Paris.

Colored Stone. 2005. Madagascar opens to foreign buyers. Colored Stone January/February 2005. http://www.colored-stone.com/stories/jan05/ madagascar.cfm

Cope, L.W. 2002. Madagascar mining - open for business. Engineering and Mining Journal 203:24-28. 
Davis, G.A. and Tilton, J.E. 2005. The resource curse. Natural Resources Forum 29:233-242.

Duffy, R. 2005. Global environmental governance and the challenge of shadow states: the impact of illicit sapphire mining in Madagascar. Development and Change 36:825-843.

Duffy, R. 2006. Non-governmental organisations and governance states: the impact of transnational environmental management networks in Madagascar. Environmental Politics 15:731-749.

Duffy, R. 2007. Gemstone mining in Madagascar: transnational networks, criminalisation and global integration. Journal of Modern African Studies 45:1-22.

Felena. 2006. Un audit environnemental est préconisé. Le Quotidien 1033, 30 septembre 2006. http://www.lequotidien.mg/article. php? art $=11914 \&$ date $=2006-09-30$

Funk, V.A., Fernanda Zermoglio, M. and Nasir, N. 1999. Testing the use of specimen collection data and GIS in biodiversity exploration and conservation decision making in Guyana. Biodiversity and Conservation 8:727-751.

Haselip, J. and Hilson, G. 2005. Winners and losers from industry reforms in the developing world: experiences from the electricity and mining sectors. Resources Policy 30:87-100.

Hilson, G. 2002. Land use competition between small- and large-scale miners: a case study of Ghana. Land Use Policy 19:149-156.

Hecht, G. 2002. Rupture-talk in the nuclear age: conjugating colonial power in Africa. Social Studies of Science 32:691-727.

Mining Journal. 2004. Madagascar. Mining Journal Special Publication. Mining Communications, London. 12pp.

Miranda, M., P. Burris, J. F. Bingcang, P. Shearman, J. O. Briones, A. L. Viña and Menard, S. 2003. Mining and critical ecosystems: mapping the risks. World Resources Institute, Washington, D.C.

Myers, N. Mittermeier, R. A., Mittermeier, C. G., da Foncesca, G. A. B. and Kent, J. 2000. Biodiversity hotspots for conservation priorities. Nature 403:853-858.

Norris, S. 2006. Madagascar defiant. Bioscience 56:960-965

Pouliquen-Young, O. 1997. Evolution of the system of protected areas in Western Australia. Environmental Conservation 24:168-181.

Ramamonjisoa, B.S. 2004. Origines et impacts des politiques de gestion des ressources naturelles à Madagascar. Schweizerische Zeitschrift für Forstwesen 155(11):2-10

Raoel. 2007. Et une protection de plus pour l'Alaotra! Tribune de Madagascar 5465 (20 January 2007).

Rép. Mad., République de Madagascar. 1999. Loi No. 99-022 portant Code Minier. http://www2.gaf.de/bpgrm/pdf/law-mining/loi99_022.pdf

Rép. Mad. 2000a. Decrêt No. 2000-170 fixant les conditions d'application de la Loi no. 99-022 du 19 Août 1999 portant Code Minier. http://www2. gaf.de/bpgrm/pdf/law-mining/decret2000_170.pdf

Rép. Mad. 2000b. Arrêté interministériel No. 12032/2000 sur la réglementation du secteur minier en matière de protection de l'environnement. http://www2.gaf.de/bpgrm/pdf/law-mining/DSTM.pdf

Rép. Mad. 2001. Loi No. 020/2001 Etablissant Régime Spécial pour les Grands Investissements dans le Secteur Minier Malagasy. http:// www2.gaf.de/bpgrm/pdf/law-mining/decret2003_784.pdf

Rép. Mad. 2003a. Décrêt No. 2003-784 fixant les condition d'application de la Loi no. 2001-031 du 08 octobre 2002 établissant Régime Spécial pour les Grands Investissements dans le Secteur Minier Malagasy. http://www2.gaf.de/bpgrm/pdf/law-mining/decret2003_784.pdf

Rép. Mad. 2003b. Evaluation environnementale sectorielle des mines. Tecsult International, Montréal. 300pp.

Rép. Mad. 2004. Arrêté interministériel № 19560/2004 Portant suspension de l'octroi de permis minier et de permis forestier dans les zones réservées comme "sites de conservation". http://www.droit-afrique. com/images/textes/Madagascar/

Rép. Mad. 2005. Arrêté Interministeriel No. 5371/2005 MEFB-MEM fixant le taux et les modalités d'assiette et de recouvrement du Droit Spécial sur les Transactions Minières (DSTM). http://www2.gaf.de/bpgrm/pdf/ law-mining/DSTM.pdf

Rép. Mad. 2007. Actualisation du plan de gestion environnemental du projet de gouvernance des ressources minérales. http://www.pgrm.mg/ index.php? option=com_docman\&task=cat_view\&gid $=14 \& \mid$ temid $=18$
Sarrasin, B. 2006. The mining industry and the regulatory framework in Madagascar: some developmental and environmental issues. Journal of Cleaner Production 14:388-396.

Thiollay, J.-M. 2002. Bird diversity and selection of protected areas in a large neotropical forest tract. Biodiversity and Conservation 11:1377-1395.

Walsh, A. 2003. "Hot money" and daring consumption in a northern Malagasy sapphire-mining town. American Ethnologist 30:290-305.

Walsh, A. 2004. In the wake of things: speculating in and about sapphires in northern Madagascar. American Anthropologist 106:225-237.

Weldon, R.G.G. 2005. Madagascar liberalizes gem trade. Professional Jeweler 23FEB2005. http://www.professionaljeweler.com/archives/ news/2005/022305story.html

Yager, T.R. 2004. The mineral industry of Madagascar. U.S. Geological Survey minerals yearbook - 2004 26:1-6 